\title{
Pengaruh Profitabilitas, Aktiva Berwujud, Ukuran Perusahaan, Pertumbuhan dan Umur Perusahaan Terhadap Struktur Modal Perusahaan (Studi Empiris pada Perusahaan Properti dan Real Estate yang Terdaftar di Bursa Efek Indonesia)
}

\author{
Ade Banani, Rayhan Fidho Baghaskoro, Najmudin \\ Jurusan Manajemen, Universitas Jenderal Soedirman, Purwokerto, Jawa Tengah, Indonesia
}

\begin{abstract}
ABSTRAK : Tujuan penelitian adalah menganalisis pengaruh profitabilitas, aktiva berwujud, ukuran perusahaan, pertumbuhan perusahaan, umur perusahaan terhadap struktur modal pada industri penghasil bahan baku yang terdaftar di Bursa Efek Indonesia periode 2012-2016. Penelitian ini melakukan analisis terhadap 17 sektor Properti dan Real Estate yang terdaftar di BEI pada periode tahun 2013 - 2018. Alat analisis yang digunakan adalah regresi linier berganda dan pengujian hipotesis menggunakan perhitungan uji t. Hasil penelitian menunjukkan bahwa profitabilitas, ukuran perusahaan, pertumbuhan perusahaan dan umur perusahaan berpengaruh positif terhadap struktur modal, sementara aktiva berwujud tidak memberikan pengaruh signifikan terhadap struktur modal.
\end{abstract}

Kata kunci : profitabilitas, aktiva berwujud, ukuran perusahaan, pertumbuhan perusahaan, umur perusahaan dan struktur modal.

ABSTRACT : The purpose of this study was to analyze the effect of profitability, tangible assets, company size, company growth, and company age toward capital structure in the raw material producing industries listed on the Indonesia Stock Exchange for the period 2012-2016. This study analyzed 17 Property and Real Estate sectors listed on the Indonesia Stock Exchange in year 2013 2018 period. The analytical tools used are multiple linear regression and hypothesis testing using $t$ test calculations. The results showed that profitability, company size, company growth and company age had a positive effect on capital structure, while tangible assets did not have a significant effect on capital structure.

Keywords: profitability, tangible assets, company size, company growth, company age and capital structure.

Email Address: a.banani@yahoo.com

\section{Pendahuluan}

Di era pembangunan seperti saat ini, persaingan di dunia usaha baik sektor industri maupun jasa menjadi semakin ketat. Kondisi ini menjadikan setiap perusahaan saling berusaha untuk dapat mempertahankan kelangsungan hidup perusahaannya (Wijaya dan Hadianto, 2008). Dalam manajemen keuangan, salah satu unsur yang perlu diperhatikan adalah mengenai seberapa besar kemampuan perusahaan dalam memenuhi kebutuhan dana yang akan digunakan untuk beroperasi dan mengembangkan usahanya. Salah satu permasalahan yang mendasar pada 
sebuah perusahaan adalah mengenai struktur modal. Struktur modal adalah perimbangan atau perbandingan antara modal asing dengan modal sendiri. Karena itu para manajer keuangan harus tetap memperhatikan biaya modal dalam menetapkan apakah kebutuhan dana perusahaan dipenuhi dengan modal sendiri atau dipenuhi dengan modal asing (Husnan, 2002:218).

Salah satu faktor yang menyebabkan terpuruknya kondisi perusahaan adalah karena banyak perusahaan melakukan pinjaman untuk melakukan ekspansi usaha dan selalu mengabaikan susunan struktur modal perusahaan. Akibatnya akan terjadi ketidaksesuaian antara sumber pendanaan dan penggunaannya (Sudarno, 2005). Seorang manajer keuangan mempunyai peranan penting dalam pengambilan keputusan pendanaan perusahaan. Proses pengambilan keputusan untuk memilih pendanaan mana yang lebih efisien sering sekali menjadi dilema bagi manajer keuangan. Dalam mengelola struktur modal, sebuah perusahaan harus sangat berhati-hati karena adanya faktor-faktor yang dapat mempengaruhi pemilihan struktur modal yang banyak dan kompleks serta mempunyai konsekuensi finansial yang berbeda-beda (Brealey dan Myer, 1991:331). Keputusan pendanaan dan rencana investasi yang dibuat oleh perusahaan dapat membentuk suatu struktur modal yang dapat meminimalkan biaya modal sehingga dapat memaksimalkan laba dalam mencapai salah satu tujuan perusahaan yaitu kesejahteraan para pemegang saham (Djakman dan Halomoan, 2001). Ada beberapa fenomena yang berkaitan dengan permasalahan struktur modal, yang berujung pada penjualan aset perusahaan karena sudah terlalu banyak hutang.

Penelitian tentang determinan dari struktur modal telah banyak sekali dilakukan di berbagai dunia. Dari banyaknya penelitian tersebut memberikan hasil penelitian yang sangat beragam. Sehingga memunculkan research gap dalam topik penelitian tersebut. Berikut ini merupakan ringkasan riset-riset terdahulu mengenai determinan dari struktur modal.

Tabel 1. Perbedaan hasil penelitian determinan struktur modal

\begin{tabular}{|c|c|c|c|}
\hline No & Peneliti/Tahun & Variabel & Hasil \\
\hline \multirow[t]{6}{*}{1} & Serghiescu and Văidean & Dependen: & \\
\hline & $(2014)$ & Struktur modal & \\
\hline & & Independen: & \\
\hline & & Profitability (ROA) & Berpengaruh negatif \\
\hline & & Size (Ln Total Aset) & Berpengaruh positif \\
\hline & & Asset structure (Aktiva berwujud) & Berpengaruh negatif \\
\hline \multirow[t]{8}{*}{2} & Thippayana & Dependen: & \\
\hline & $(2015)$ & Struktur modal & \\
\hline & & Independen: & \\
\hline & & Firm Size & Berpengaruh positif \\
\hline & & Profitability & Berpengaruh negatif \\
\hline & & Asset tangibility & Berpengaruh positif \\
\hline & & Growth & Tidak berpengaruh \\
\hline & & Volatility & Berpengaruh positif \\
\hline \multirow[t]{6}{*}{3} & Mau, Prasasyaningsih, & Dependen: & \\
\hline & danKristanti & Struktur modal & \\
\hline & $(2015)$ & Independen: & \\
\hline & & Profitabilitas & Berpengaruh negatif \\
\hline & & Umur & Tidak berpengaruh \\
\hline & & Ukuran Perusahaan & Berpengaruh positif \\
\hline \multirow[t]{6}{*}{4} & Ariyani, Pangestuti, & Dependen: & \\
\hline & dan Raharjo & Struktur modal & \\
\hline & $(2018)$ & Independen: & \\
\hline & & Asset structure & Tidak berpengaruh \\
\hline & & Profitability & Berpengaruh negatif \\
\hline & & Company size & Berpengaruh positif \\
\hline
\end{tabular}


$5 \quad$ Acaravci

(2015)

6 Sakinah dan Anggodo (2014)

$8 \quad$ Noryati (2015)

\author{
Company growth \\ Dependen: \\ Struktur modal \\ Independen: \\ Growth \\ Size \\ Profitability \\ Tangibility \\ Non-Debt Tax Shields \\ Dependen: \\ Struktur modal \\ Independen: \\ Growth \\ Firm size \\ Profitability \\ Dependen: \\ Strutur modal \\ Independen: \\ Firm size \\ Asset structure (aktiva berwujud) \\ Growth \\ Profitability \\ Dependen \\ Struktur modal \\ Independen: \\ Tangibility \\ Profitability \\ Firm size \\ Firm growth \\ Non-debt tax shield \\ Earning volatility \\ Liquidity \\ Firm age
}

Asset tangibility Tidak berpengaruh

Berpengaruh negatif

Berpengaruh negatif

Berpengaruh negatif

Berpengaruh negatif

Berpengaruh positif

Berpengaruh negatif

Berpengaruh positif

Berpengaruh positif

Berpengaruh negatif

Berpengaruh negatif

Berpengaruh negatif

Berpengaruh negatif
Adanya perbedaan atau research gap pada penelitian terdahulu membuat peneliti tertarik untuk melakukan penelitian kembali mengenai topik struktur modal untuk memperkaya hasil riset ilmiah khususnya pada topik struktur modal.

Penelitian ini mengambil subjek pada perusahaan sektor properti dan real estate yang terdaftar di Bursa Efek Indonesia periode 2013-2018. Sektor properti dan real estate memegang peranan penting dalam bidang perekonomian dan pembangunan di Indonesia. Sektor ini juga menjadi salah satu indikator untuk menilai perkembangan perekonomian suatu negara. Data BPS (2017, bps.go.id) menyebutkan bahwa sumbangan sektor properti dan real estate terhadap perekonomian Indonesia yaitu sebesar $10.38 \%$. Selain itu sektor ini dinilai memiliki prospek yang baik di masa yang akan datang karea saat ini Pemerintah Indonesia begitu giat dengan program infrastrukturnya yang bisa memberikan sinyal positif untuk peluang dan perkembangan sektor properti dan real estate itu sendiri.

Berkaitan dengan keputusan struktur modal pada sektor properti dan real estate, ada fenomena yang muncul ketika peneliti melakukan riset pendahuluan pada keputusan pendanaan melalui utang pada sektor properti dan real estate. Sesuai dengan periode pengamatan penelitian ini dari tahun 2013 s.d 2018 total utang pada sektor properti mengalami peningkatan secara kontinyu. Pada tahun 2013 rata-rata total utang pada sektor properti dan real estate yaitu sebesar $\mathrm{Rp}$ 3,261,865 (dalam juta) kemudian pada tahun 2014 meningkat menjadi Rp 3,829,218 (dalam juta) atau tumbuh sebesar $17 \%$, pada tahun 2015 mengamali peningkatan yang lebih besar lagi menjadi $\mathrm{Rp}$ 4,645,108 (dalam juta) atau tumbuh sebesar 21\%, pada tahun 2016 
pertumbuhan utang sektor properti dan real estate sama dengan tahun sebelumnya yaitu tumbuh sebesar $21 \%$ atau menjadi $\mathrm{Rp}$ 5,621,202 (dalam juta), kemudian di tahun 2017 pertumbuhan utang meningkat lagi menjadi sebesar $28 \%$ atau total utang sektor properti dan real estate pada tahun 2017 adalah sebesar Rp 7,197,550 (dalam juta).

Tabel 2. Rata-rata total utang sektor properti dan real estate periode 2013-2018

\begin{tabular}{ccccc}
\hline Tahun & $\begin{array}{c}\text { Rata-Rata } \\
\text { Total Utang } \\
\text { (dalam jutaan) }\end{array}$ & $\begin{array}{c}\text { Pert } \\
\text { umb } \\
\text { uhan }\end{array}$ & $\begin{array}{c}\text { Debt to } \\
\text { Equity Ratio } \\
(\%)\end{array}$ & $\begin{array}{c}\text { Pertumb } \\
\text { uhan }\end{array}$ \\
\hline 2013 & $3,261,865$ & & 1.0456 & \\
2014 & $3,829,218$ & $17 \%$ & 1.0323 & $-1.27 \%$ \\
2015 & $4,645,108$ & $21 \%$ & 0.9079 & $-12.04 \%$ \\
2016 & $5,621,202$ & $21 \%$ & 0.8618 & $-5.08 \%$ \\
2017 & $7,197,550$ & $28 \%$ & 0.9594 & $11.33 \%$ \\
2018 & $8,120,307$ & $13 \%$ & 0.9637 & $0.44 \%$ \\
\hline
\end{tabular}

Berdasarkan riset pendahuluan juga ditemukan bahwa dari 48 perusahaan pada sektor properti dan real estate terdapat 17 perusahaan yang rasio debt to equity nya lebih dari $100 \%$, artinya sebagian perusahaan tersebut memilih menggunakan dana utang yang lebih besar dibanding modal sendiri. Hal ini, menarik untuk diteliti terkait dengan faktor apa yang digunakan perusahaan dalam menentukan struktur modalnya. Sehingga, sebagian perusahaan tersebut menggunakan utang yang lebih banyak dibandingkan dengan modal yang dimiliki.

Di samping fenomena itu, Pemeringkat Efek Indonesia (Pefindo) menyematkan outlook negatif kepada emiten di sektor properti dan real estate diantaranya yaitu PT Summarecon Agung Tbk. (SMRA), PT Surya Semesta Internusa Tbk. (SSIA), PT Modernland Realty Tbk. (MDLN), PT Agung Podomoro Land Tbk. (APLN), PT Intiland Development Tbk. (DILD), dan PT Duta Anggada Realty Tbk. (DART). Outlook negative yang dimaksudkan di sini adalah menurunnya tingkat kemampuan membayar hutang perusahaan.

Penelitian ini mengambil lima variabel bebas untuk memprediksi struktur modal. Variabel tersebut yaitu profitabilitas, aktiva berwujud, ukuran perusahaan, pertumbuhan perusahaan dan umur perusahaan.
Variabel pertama yaitu profitabilitas. Profitabilitas adalah kinerja perusahaan dalam menghasilkan laba melalui penggunaan asetnya (Miskhin \& Eakins, 2006). Ada dua teori umum dalam hubungan antara profitabilitas dengan struktur modal. Teori pertama yaitu tradeoff theory yang memandang bahwa perusahaan dengan laba tinggi akan menggunakan utang tinggi untuk mendapatkan manfaat pajak, sedangkan teori kedua yaitu pecking order theory memandang bahwa perusahaan dengan profitabilitas yang tinggi cenderung lebih sedikit dalam menggunakan utang, karena lebih memilih menggunakan laba ditahan dibanding utang.

Variabel kedua adalah aktiva berwujud (tangibility). Menurut Rajan dan Zingales (1995) tangibilitas adalah variabel penting dalam keputusan pembiayaan perusahaan, karena aset berwujud bertindak sebagai jaminan dan memberikan keamanan kepada pemberi pinjaman jika terjadi kesulitan keuangan. Biasanya, aset tidak berwujud mengandung lebih banyak informasi asimetris tentang nilai daripada aset berwujud; lebih mudah bagi pemberi pinjaman untuk menetapkan nilai aset berwujud daripada aset tidak berwujud. Selain itu, sangat mungkin bahwa dalam menghadapi kemungkinan kebangkrutan, aset tidak berwujud seperti niat baik akan cepat menghilang, sehingga mengurangi nilai bersih perusahaan dan semakin mempercepat kemungkinan kebangkrutannya. Oleh karena itu, orang dapat berargumen bahwa perusahaan dengan persentase lebih besar dari total aset mereka yang terdiri dari aset berwujud akan memiliki kapasitas yang lebih tinggi untuk meningkatkan hutang. Jaminan juga melindungi pemberi pinjaman dari masalah moral hazard yang disebabkan oleh konflik yang diakhiri pemegang saham (Jensen dan Meckling, 1976). Dengan demikian, perusahaan dengan aset berwujud yang lebih tinggi diharapkan memiliki tingkat utang yang tinggi.

Variabel ketiga adalah ukuran perusahaan. Perusahaan berukuran besar lebih memiliki kemandirian dalam hal pendanaan sehingga dianggap memiliki kemungkinan yang kecil dalam mengalami kebangkrutan, dan karenanya menarik lebih banyak utang. Penjelasan tersebut adalah pandangan dari Trade-off Theory. Dengan kata lain Trade-off 
Theory memandang rasio utang memiliki hubungan positif dengan ukuran perusahaan (Titman dan Wessels, 1988). Pecking Order Theory memiliki pandangan yang berbeda yaitu bahwa perusahaan berukuran besar menimbulkan asimetri informasi yang lebih besar dan, karenanya menarik lebih sedikit utang. Dengan kata lain Pecking Order Theory memandang adanya hubungan negatif antara ukuran perusahaan dan struktur modal, hal tersebut disebabkan karena perusahaan besar memiliki kemampuan pembiayaan melalui penerbitan saham daripada pembiayaan utang; dengan demikian, perusahaan yang lebih besar menggunakan lebih sedikit hutang dalam struktur modal mereka (Deloof dan Overfelt, 2008)

Variabel keempat yaitu pertumbuhan perusahaan. Pertumbuhan perusahaan adalah peluang atau peluang yang harus dimiliki perusahaan untuk selalu meningkatkan kinerja dengan mencapai tingkat pertumbuhan yang optimal. Dana akan semakin dibutuhkan jika perusahaan dalam fase pertumbuhan. Banyak dana dibutuhkan untuk membiayai pengembangan bisnis. Padahal dana internal perusahaan yang dimiliki harus terbatas dan kurang mampu memenuhi kebutuhan modal bisnisnya (Ariyani et al, 2018). Kondisi tersebut sejalan dengan teori pecking order yang memandang bahwa perusahaan dengan tingkat pertumbuhan yang tinggi cenderung memiliki tingkat utang yang tinggi.

Variabel terakhir yaitu umur perusahaan. Umur perusahaan menurut Ulum (2009:173) adalah bagian dari dokumentasi yang menunjukkan tentang apa yang tengah dan yang akan diraih oleh perusahaan. Umur perusahaan juga didefinisikan seberapa lama suatu perusahaan mampu untuk bertahan, bersaing, dan mengambil kesempatan bisnis yang ada dalam perekonomian Perusahaan yang sudah lama berdiri, kemungkinan sudah banyak pengalaman yang diperoleh. Semakin lama umur perusahaan, semakin banyak informasi yang telah diperoleh masyarakat tentang perusahaan tersebut. Hal ini akan menimbulkan kepercayaan konsumen terhadap perushaan-perusahaan tersebut (Syari'i, 2013). Kondisi tersebut sejalan dengan pandangan teori pecking order yang menyatakan bahwa perusahaan dengan usia yang semakin lama cenderung memiliki utang yang rendah.
Secara umum tujuan penelitian ini adalah untuk menyelidiki perkembangan tentang pendanaan perusahaan atau struktur modal di perusahaan Property dan Real Estate yang terdaftar di BEI pada periode 2013-2018 serta untuk mengetahui faktor-faktor yang dapat mempengaruhi struktur modal tersebut. Secara spesifik fokus penelitian ini adalah untuk: Menganalisis pengaruh profitabilitas, aktiva berwujud, ukuran perusahaan, pertumbuhan perusahaan, dan umur perusahaan terhadap struktur modal.

\section{Tinjauan Pustaka dan Pengembangan Hipotesis}

\section{Struktur Modal}

Menurut Sugiarto (2009:1) struktur modal perusahaan merupakan bagian dari struktur keuangan perusahaan yang mengulas tentang cara perusahaan mendanai aktivanya. Mengutip dari Bernstein \& Wild (1998:583) mereka menjelaskan bahwa struktur modal mengarah pada pendanaan perusahaan yang menggunakan utang jangka panjang, saham preferen ataupun modal pemegang saham. Pada hakikatnya, struktur modal yang merupakan kombinasi utang dan ekuitas dalam struktur keuangan jangka panjang perusahaan lebih menggambarkan target komposisi utang dan modal sendiri (ekuitas) dalam jangka panjang pada suatu perusahaan.

Struktur modal adalah campuran spesifik antara hutang jangka panjang dan ekuitas yang digunakan perusahaan untuk membiayai operasinya. Dua hal tersebut merupakan fokus dari manajer keuangan, untuk memutuskan berapa dana yang harus dipinjam perusahaan dan apa sumber dana paling murah untuk membiayai operasional perusahaan (Ross, et al, 2008:3).

Secara umum, struktur modal menekankan pada kombinasi hutang dan ekuitas untuk membiayai perusahaan. Berbagai keputusan pembiayaan sangat penting untuk kesejahteraan keuangan perusahaan (Brigham dan Houston, 2011:56). Keputusan yang salah tentang struktur modal dapat menyebabkan kesulitan keuangan dan akhirnya menyebabkan kebangkrutan. Manajemen suatu perusahaan menetapkan struktur modalnya sedemikian rupa sehingga nilai perusahaan dapat dimaksimalkan. Banyak penelitian telah dilakukan untuk menemukan struktur modal 
yang optimal, meskipun banyak sekali penelitian yang telah dilakukan pada struktur modal, tidak ada metode khusus yang dikembangkan untuk manajer untuk menentukan struktur modal yang optimal (Sheikh dan Wang, 2011).

\section{Teori Struktur Modal}

Modigliani-Miller's theorem (1958)

Modigliani dan Miller adalah orang pertama yang menetapkan teori struktur modal yang optimal. Dalam teori ini, mereka mengembangkan dua proposisi: (1) klaim pertama bahwa tingkat leverage perusahaan tidak mempengaruhi nilai pasarnya, yang konstan terlepas dari proporsi utang dan ekuitas yang dipilih dalam pembiayaan perusahaan, (2) proposisi kedua menggambarkan biaya rata-rata tertimbang perusahaan tidak terpengaruh oleh leverage perusahaan.

Meskipun tidak mempertimbangkan biaya kebangkrutan, pajak dan biaya agen lainnya dan di sisi lain itu tidak membedakan antara perorangan dan badan hukum ketika merujuk pada proses pinjaman, teorema Modigliani dan Miller dianggap yang referensi paling penting dari seluruh teori struktur modal (Modigliani dan Miller, 1958 dalam Serghiescu \& Vaidean, 2014)

\section{Trade-Off Theory}

Dikutip dari Alipour et al (2015) "Jensen dan Meckling (1976) membuat teori trade-off (TOT). Berdasarkan teori ini, terdapat struktur modal yang optimal dan struktur modal suatu perusahaan dapat ditentukan dengan menciptakan keseimbangan antara efek pajak, biaya agensi, biaya kebangkrutan dan sebagainya. Ini menegaskan bahwa struktur modal optimal perusahaan dapat ditentukan oleh biaya agensi. Untuk mengurangi biaya agensi, struktur optimal kepemilikan dan hutang harus ditentukan (Jensen dan Meckling, 1976). Jensen dan Meckling (1976) adalah yang pertama untuk memeriksa struktur modal dari perspektif biaya agensi. TOT menyatakan bahwa keuntungan, ukuran dan pertumbuhan secara positif terkait dengan struktur modal karena mereka semua adalah proksi untuk manfaat pajak terkait utang yang tinggi dan/atau biaya kebangkrutan terkait utang yang rendah. Di sisi lain, karya Jensen dan Meckling dan Myers (1977) memberikan bukti tentang hubungan positif antara rasio utang perusahaan dan aset yang dijaminkan".

Teori Trade-Off, muncul sebagai hasil dari diskusi tentang teorema ModiglianiMiller, klaim bahwa suatu perusahaan akan meminjam sampai pada titik di mana nilai marginal dari pengurangan pajak atas bunga yang dibayarkan akan diimbangi dengan peningkatan nilai sekarang (Myers, 2001 dalam Serghiescu \&Vaidean, 2014).

\section{Teori Packing Order}

Dikutip dari Alipour et al (2014) "Myers (1984) mendirikan teori pecking order (POT), yang didasarkan pada keberadaan asimetri informasi yang dihipotesiskan antara pemegang saham, manajer, dan kreditor ketika hutang atau ekuitas digunakan. POT menolak keberadaan struktur modal yang optimal dan berpendapat bahwa perusahaan biasanya mengikuti urutan kekuasaan dalam keuangan perusahaan; yaitu, lebih memilih pendanaan internal daripada pendanaan eksternal dan lebih memilih pendanaan utang daripada pendanaan ekuitas.

Myers dan Majluf (1984) dan Myers (1984) dalam Serghiescu \& Vaidean (2014) menjelaskan asimetri informasi yang ada antara manajer, pemegang saham dan investor, sehingga perusahaan lebih memilih untuk membiayai investasi mereka terlebih dahulu, dengan sumber daya internal, kemudian dengan modal pinjaman, dan akhirnya dengan menggunakan ekuitas yang disediakan oleh pemegang saham.

\section{Agency Theory}

Teori agensi mengasumsikan bahwa kepentingan manajer dan pemegang saham tidak selaras dengan sempurna dan bahwa manajer, meskipun bertindak sebagai agen pemegang saham, tidak akan selalu bertindak sesuai dengan kepentingan terbaik investor, tetapi mereka akan mengejar keuntungan pribadi mereka (Jensen dan Meckling, 1976 dalam Serghiescu \& Vaidean, 2014).

Jensen dan Meckling

memperkenalkan konsep biaya agensi, yang dalam pandangan mereka termasuk biaya yang dikeluarkan oleh kepala sekolah dalam memantau manajer mereka, biaya yang terkait dengan kewajiban agen dan kerugian residual lainnya. Selain itu, mereka menyoroti dua jenis konflik kepentingan yang menghasilkan biaya 
agensi: konflik antara pemegang saham dan manajer dan konflik antara pemegang saham dan kreditor yang timbul ketika tingkat utang perusahaan meningkat dan pemegang saham dapat memperoleh manfaat atas nama kreditor jika terjadi wanprestasi.

\section{Equity Market Timing Theory}

Baker dan Wurgler (2002) telah menyarankan teori baru struktur modal: "Market Timing Theory of Capital Structure". Teori ini menyatakan bahwa struktur modal saat ini adalah hasil kumulatif dari upaya masa lalu untuk mengatur waktu pasar ekuitas. Menurut teori ini, fluktuasi harga saham harus memiliki efek pada struktur modal perusahaan dan tidak ada struktur modal yang optimal. Selain itu, teori ini menunjukkan bahwa perusahaan menerbitkan surat utang dan ekuitas hanya ketika nilai pasar mereka dalam kondisi baik, dan ketika nilai pasar mereka lebih rendah, mereka membeli kembali saham mereka.

Meskipun tidak mendefinisikan struktur modal yang optimal, teori market timing menunjukkan beberapa kondisi spesifik pasar modal dan kondisi ekonomi makro di suatu negara dapat mempengaruhi struktur modal perusahaan yang terdaftar di bursa. Berusaha selaras dengan pasar menyiratkan bahwa perusahaan akan mengeluarkan saham dengan harga tinggi dan kemudian mencoba menebus atau membeli kembali saham-saham ini dengan harga lebih rendah. Penerima manfaat dari praktik ini adalah pemegang saham yang ada dan para manajer yang mengejar kepentingan para investor, diharapkan untuk melakukan sinkronisasi dengan pasar. (Serghiescu \& Vaidean, 2014).

$$
\text { Equity market timing theory }
$$
menyatakan bahwa perusahaan-perusahaan akan menerbitkan equity pada saat market value tinggi dan akan membeli kembali equity pada saat market value rendah. Tujuan dari melakukan equity market timing adalah untuk memanfaatkan fluktuasi sementara yang terjadi pada biaya ekuitas terhadap biaya komponen modal lainnya. Akibatnya, fluktuasi harga saham mempengaruhi struktur modal. Hal ini menunjukkan bahwa equity market timing berpengaruh terhadap struktur modal perusahaan (Baker dan Wurgler, 2002).

\section{Profitabilitas}

Menurut Sartono (2010:122) profitabilitas adalah kemampuan perusahaan memperoleh laba dalam hubungannya dengan penjualan, total aktiva maupun modal sendiri. Irawati (2006:22) menyatakan bahwa rasio keuntungan atau profitability ratio adalah rasio yang digunakan untuk mengukur efisiensi penggunaan aktiva perusahaan atau merupakan kemampuan suatu perusahaan untuk menghasilkan laba selama periode tertentu (biasanya semesteran, triwulanan dan lain-lain) untuk melihat kemampuan perusahaan dalam beroperasi secara efisien.

Profitabilitas adalah hubungan antara pendapatan dan biaya yang dihasilkan dengan menggunakan aset perusahaan baik saat ini dan tetap dalam kegiatan produktif. Suatu perusahaan dapat meningkatkan profitabilitas mereka dengan mengurangi biaya mereka atau meningkatkan pendapatan mereka dengan penjualan. Profitabilitas adalah kinerja perusahaan dalam menghasilkan laba dengan menggunakan aset perusahaan baik saat ini dan tetap dalam kegiatan produktif yang ditunjukkan oleh tingkat pengembalian aset (Gitman \& Zutter, 2012:92)

\section{Aktiva Berwujud}

Menurut Hidayat (2011:4) bahwa definisi aset adalah barang yang dalam pengertian hukum disebut sebagai suatu benda, yang terdiri atas benda abergerak dan juga benda tidak bergerak, baik yang berwujud (tangible) maupun yang tidak berwujud (intangible). Keseluruhan dari hal tersebut mencakup dalam aktiva atau aset atau harta aset dari suatu instansi, organisasi, badan usaha ataupun dari individu perorangan.

Tangibility merupakan salah satu variabel penting dalam menentukan keputusan pendanaan, karena aktiva tetap yang dimiliki oleh suatu perusahaan dapat dijadikan collateral bagi pihak kreditur dalam melakukan pinjaman (Joni dan Lina, 2010). Perusahaan yang tidak mempunyai aktiva yang dapat digunakan sebagai collateral oleh perusahaan dalam melakukan pinjaman, maka perusahaan tersebut akan cenderung menggunakan hutang dalam jumlah besar (Brigham dan Houston, 2011:188). Dengan hasil perbandingan antara aktiva tetap total aset (aktiva) akan menghasilkan asset tangibility, artinya semakin banyak jaminan yang dikeluarkan maka perusahaan akan semakin mudah untuk 
mendapatkan hutang maksudnya investor akan lebih mempercayai jika perusahaan mengalami kebangkrutan, maka aktiva tetap yang tersedia dapat digunakan untuk melunasi hutang yang dimiliki perusahaan.

Tangibilitas aset diartikan sebagai ukuran untuk tingkat kredit yang dapat ditawarkan perusahaan kepada kreditornya. Rasio aktiva tetap terhadap total aset yang tinggi memberi kreditor tingkat keamanan yang tinggi karena mereka dapat melikuidasi aset jika terjadi kebangkrutan. Tangibilitas adalah aset fisik yang memiliki periode penggunaan yang relatif lama dalam operasi bisnis seperti tanah, bangunan, mesin, dan konstruksi dalam penyelesaian yang dapat ditawarkan sebagai jaminan kepada kreditor jika terjadi kebangkrutan, tingkat aset tetap total yang tinggi memberikan tingkat keamanan kepada kreditor (Baker \& Martin, 2011).

\section{Ukuran Perusahaan}

Menurut Hartono (2008:254) ukuran perusahaan (firm size) adalah sebagai berikut : "besar kecilnya perusahaan dapat diukur dengan total aktiva/ besar harta perusahaan dengan menggunakan perhitungan nilai logaritma total aktiva"

Ukuran perusahaan dapat diartikan sebagai besar kecilnya perusahaan. Ukuran perusahaan memiliki peranan penting dalam menentukan pilihan struktur modal yang akan digunakan oleh suatu perusahaan. Perusahaan besar akan lebih mudah memperoleh modal di pasar modal dibandingkan dengan perusahaan kecil karena perusahaan besar memiliki probabilitas yang lebih besar untuk memenangkan persaingan atau bertahan dalam industri. Perusahaan besar cenderung untuk mengungkapkan lebih banyak informasi kepada investor luar daripada perusahaan kecil (Nasruddin, 2004). Perusahaan yang semakin besar maka perusahaan tersebut akan membutuhkan modal yang tinggi pula, sehingga perusahaan dapat mengambil kebijakan untuk menambah modal dari pihak luar (hutang).

Menurut Machfoedz (1994) menyatakan bahwa: "Ukuran perusahaan adalah suatu skala dimana dapat diklasifikasikan besar kecil perusahaan menurut berbagai cara (total aktiva, log size, nilai pasar saham, dan lainlain). Pada dasarnya ukuran perusahaan hanya terbagi dalam 3 kategori yaitu perusahaan besar, perusahaan menengah dan perusahaan kecil.

Ukuran perusahaan dilihat dari total aset yang dimiliki oleh perusahaan yang dapat dipergunakan untuk kegiatan operasi perusahaan. Jika perusahaan memiliki total aset yang besar, pihak manajemen lebih leluasa dalam mempergunakan aset yang ada diperusahaan tersebut. Jika dilihat dari sisi manajemen, kemudahan yang dimilikinya dalam mengendalikan perusahaan akan meningkatkan nilai perusahaan. Ukuran perusahaan yang besar memudahkan perusahaan dalam masalah pendanaan. Perusahaan umumnya memiliki fleksibilitas dan aksebilitas yang tinggi dalam masalah pendanaan melalui pasar modal. Kemudahan ini bisa ditangkap sebagai informasi yang baik. Ukuran yang besar dan tumbuh bisa merefleksikan tingkat profit mendatang (Suharli, 2006).

\section{Pertumbuhan Perusahaan}

Menurut Kasmir (2012:107) Rasio pertumbuhan (Growth Ratio) merupakan rasio yang menggambarkan kemampuan perusahaan mempertahankan posisi ekonominya di tengah pertumbuhan perekonomian dan sektor usahanya.

Menurut Saidi (2004) perusahaan dengan tingkat pertumbuhan tinggi kemungkinan akan kekurangan pendapatan untuk mendanai pertumbuhan tinggi tersebut secara internal. Pertumbuhan penjualan yang relatif stabil dapat lebih aman memperoleh lebih banyak pinjaman dan menanggung beban tetap yang lebih tinggi dibandingkan dengan perusahaan yang penjualannya tidak stabil. Sebaliknya, menurut Setyawan dan Laksito (2008) perusahaan dengan tingkat pertumbuhan rendah, kebutuhan modal baru relatif kecil, sehingga dapat dipenuhi oleh laba ditahan.

\section{Umur Perusahaan}

Umur perusahaan yaitu seberapa lama suatu perusahaan mampu untuk bertahan, bersaing, dan mengambil kesempatan bisnis yang ada dalam perekonomian (Syafi'i, 2013). Perusahaan yang sudah lama berdiri, kemungkinan sudah banyak pengalaman yang diperoleh. Semakin lama umur perusahaan, semakin banyak informasi yang telah diperoleh 
masyarakat tentang perusahaan tersebut.Semakin tua umur perusahaan, justru perusahaan akan mengurangi proyek yang berisiko, hal ini tentu akan sangat mengurangi dari risiko gagal bayar dan mengurangi biaya utang perusahaan.

\section{Pengembangan Hipotesis}

Pengaruh Profitabilitas terhadap Struktur Modal

Berdasarkan Pecking Order Theory perusahaan dengan profitabilitas lebih tinggi memiliki rasio utang lebih sedikit. Faktanya, perusahaan dengan tingkat proftabilitas yang tinggi tidak perlu pembiayaan eksternal dan sering menggunakan pembiayaan internal. Karena alasan itu, mereka memiliki lebih sedikit hutang dalam struktur modal mereka. Ini menunjukkan bahwa perusahaan yang sangat menguntungkan akan cenderung mendanai investasi dengan laba ditahan daripada menggunakan utang (Lemmon dan Zender, 2010).

Profitabilitas adalah kemampuan perusahaan memperoleh laba dalam hubungannya dengan penjualan, total aktiva maupun modal sendiri. Tingkat pengembalian yang tinggi memungkinkan untuk membiayai sebagian besar kebutuhan pendanaan dengan dana yang dihasilkan secara internal. Tingkat pengembalian yang tinggi atas investasi menjadikan penggunaan hutang yang relatif kecil. Karena itu perusahaan yang mampu mendapatkan keuntungan yang tinggi (profitable) akan cenderung banyak memanfaatkan dana sendiri untuk keperluan investasi (Sartono dan Sriharto, 2010:122).

Berdasarkan studi literatur terhadap jurnal-jurnal sebelumnya hampir semua jurnal menyatakan bahwa profitabilitas berpengaruh negatif terhadap struktur modal. Penelitian tersebut dilakukan oleh Serghiescu and Vaidem (2014), Thippayana (2015), Mau et al (2015), Ariyani et al (2018), Acaravci (2015), Sakinah dan Anggono (2014), Alipour et al (2015) dan Noryati (2015).

Berdasarkan uraian tersebut maka dapat dirumuskan hipotesis sebagai berikut:

$\mathrm{H}_{1}$ : Profitabilitas berpengaruh negatif
terhadap struktur modal.

Pengaruh Aktiva berwujud terhadap Struktur Modal
Perusahaan yang memiliki lebih banyak aktiva berwujud memiliki akses yang lebih besar untuk meminjam uang. Ini karena aktiva berwujud dapat digunakan sebagai jaminan, yang merupakan pembayaran yang dijamin jika perusahaan menjadi tidak mampu membayarkembali utangnya. Selain menguntungkan kreditor, jaminan juga bermanfaat bagi perusahaan mencegah perusahaan dari harus bangkrut ketika utang tidak dapat dibayar (Murhadi, 2011). Karena itu, tangibilitas yang lebih tinggi dari aset perusahaan seharusnya diikuti oleh tingkat hutang yang lebih tinggi.

Studi terhadap jurnal-jurnal terdahulu seperti yang telah dilakukan oleh Murhadi (2011), Chandra (2017), Thippayana (2015), Noryati (2015) menemukan bahwa aktiva berwujud berpengaruh positif terhadap struktur modal. Berdasarkan uraian tersebut maka dapat dirumuskan hipotesis sebagai berikut.

$\mathrm{H}_{2}$ : Aktiva berwujud berpengaruh positif terhadap struktur modal

Pengaruh Ukuran Perusahaan terhadap Struktur Modal

Menurut Tradeoff Theory, rasio utang memiliki hubungan positif dengan ukuran perusahaan, karena perusahaan yang lebih besar cenderung lebih terdiversifikasi dan memiliki varian laba yang lebih rendah, memungkinkan mereka untuk mentolerir rasio utang yang tinggi. Selain itu, Pecking Order Theory menjelaskan bahwa perusahaan berukuran besar menimbulkan asimetri informasi yang lebih besar, selain itu perusahaan besar memiliki lebih banyak akses ke pendanaan eksternal (Alipour et al, 2015).

Studi literatur terhadap berbagai jurnal terdahulu yang telah dilakukan oleh Noryati (2015), Ariyani et al (2018), Mau et al (2015), Wahome et al (2015) yang dalam hasil penelitiannya mendapati bahwa ukuran perusahaan berpengaruh positif terhadap struktur modal. Berdasarkan uraian tersebut maka dapat dirumuskan hipotesis sebagai berikut.

$\mathrm{H}_{3}$ : Ukuran perusahaan berpengaruh positif terhadap struktur modal

Pengaruh Pertumbuhan Perusahaan terhadap Struktur Modal

Perusahaan dengan peluang pertumbuhan tinggi akan memiliki proporsi kapasitas utang yang tinggi. Temuan penelitian 
dilakukan oleh Tronyeva (2013) menemukan pertumbuhan perusahaan memiliki dampak yang signifikan dan positif pada struktur modal, mendukung teori pecking order. Perusahaan dengan tingkat pertumbuhan tinggi kemungkinan akan kekurangan pendapatan untuk mendanai pertumbuhan tinggi tersebut secara internal. Pertumbuhan penjualan yang relatif stabil dapat lebih aman memperoleh lebih banyak pinjaman dan menanggung beban tetap yang lebih tinggi dibandingkan dengan perusahaan yang penjualannya tidak stabil (Saidi 2004). Sebaliknya, perusahaan dengan tingkat pertumbuhan rendah, kebutuhan modal baru relatif kecil, sehingga dapat dipenuhi oleh laba ditahan (Setyawan dan Laksito, 2008). Sartono (1998) dalam Sukarno (2004) berpendapat bahwa perusahaan dengan tingkat pertumbuhan tinggi cenderung menggunakan sumber dana dari luar.

Studi literatur terhadap jurnal sebelumnya yang telah dilakukan oleh Noryati (2015) justru menemukan hasil yang berbeda yaitu bahwa pertumbuhan perusahaan berpengaruh positif terhadap struktur modal. Berdasarkan uraian tersebut maka dapat dirumuskan hipotesis sebagai berikut:

$\mathrm{H}_{4}$ : Pertumbuhan perusahaan berpengaruh positif terhadap struktur modal

\section{Pengaruh Umur Perusahaan terhadap Struktur Modal}

Teori pecking order menyatakan bahwa penggunaan pembiayaan utang menurun seiring dengan bertambahnya usia perusahaan. Argumen untuk hipotesis ini adalah bahwa perusahaan sudah memiliki laba ditahan yang cukup untuk mendanai operasinya, sehingga tidak menemukan alasan untuk mencari pendanaan eksternal melalui utang atau ekuitas (Noryati, 2015). Salah satu studi terkemuka yang diperkenalkan oleh Hall et al. (2004) menyimpulkan bahwa umur perusahaan memiliki hubungan negatif dengan hutang jangka pendek dan jangka panjang di Inggris. Berdasarkan uraian tersebut maka dapat dirumuskan hipotesis sebagai berikut:

$\mathrm{H}_{5}$ : Umur perusahaan berpengaruh negatif terhadap struktur modal

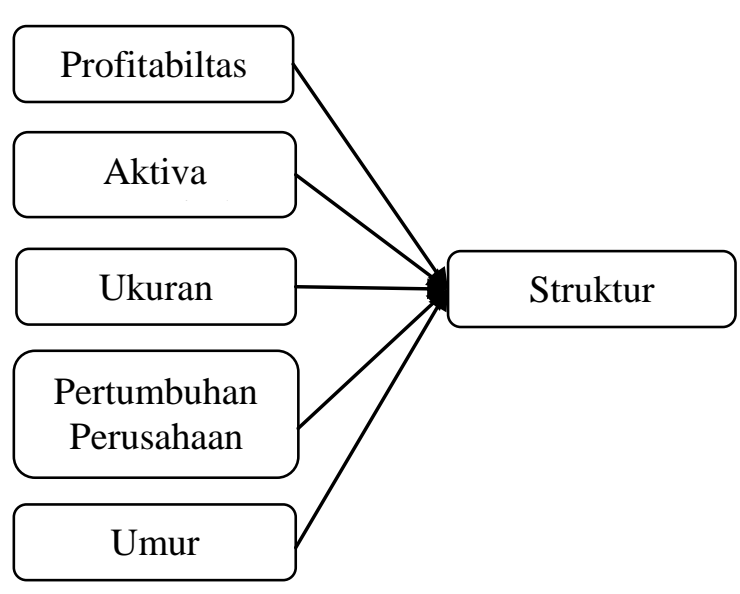

Gambar 2.1 Model Penelitian

\section{Metodologi Penelitian}

Penelitian ini merupakan penelitian kausalitas yaitu penelitian yang ingin mencari penjelasan dalam bentuk hubungan sebab akibat antar beberapa konsep atau variabel dalam manajemen, yang selanjutnya kemudian akan dilakukan pengujian hipotesis (Ferdinand, 2014:7). Objek penelitian dalam penelitian ini merupakan variabel-variabel yang diteliti yang terdiri dari profitabilitas, aktiva berwujud, ukuran perusahaan, pertumbuhan perusahaan, umur perusahaan, dan struktur modal. Penelitian ini mengambil populasi pada semua perusahaan pada sektor Properti dan Real Estate yang terdaftar di BEI pada periode tahun 2013-2018. Pengambilan sampel dalam penelitian ini menggunakan metode purpossive sampling, yaitu perusahaan akan menjadi sampel jika memenuhi beberapa kriteria tertentu. Adapun kriteria sampel penelitian ini yaitu sebagai berikut: (1) Perusahaan mempublikasikan laporan keuangan/laporan tahunan secara konsisten pada periode 20132018 (2) Perusahaan menyajikan data variabel yang dibutuhkan dalam penelitian ini secara lengkap dan konsisten pada periode 2013-2018 (3) Perusahaaan tidak mengalami delisting pada periode 2013-2018 (4) Perusahaan tidak mengalami defisiensi modal, karena defisiensi modal membuat ekuitas menjadi negatif, sehingga sering membuat data menjadi tidak normal. Data penelitian pada penelitian ini diperoleh dari data sekunder yaitu data yang 
sudah tersedia dalam laporan keuangan atau laporan tahunan yang dipublikan oleh perusahaan pada sektor industri penghasil bahan baku. Laporan keuangan tersedia di website resmi Bursa Efek Indonesia yaitu www.idx.co.id.

\section{Definisi Konseptual dan Operasional Variabel}

\section{Struktur Modal}

Struktur modal adalah cara perusahaan membiayai dirinya sendiri dengan menggabungkan utang dan ekuitas (Ross et al., 2008)

Struktur modal pada penelitian ini diproksikan dengan debt to equity ratio. Debt to equity ratio dihitung dengan cara membagi nilai total utang terhadap total equitas, rumus debt to equity ratio adalah sebagai berikut (Hanafi dan Halim, 2012:79):

Struktur Modal (DER) $=\frac{\text { Total Debt }}{\text { Total Equity }} \times 100 \%$

\section{Profitabilitas}

Menurut Sartono (2010:122) profitabilitas adalah kemampuan perusahaan memperoleh laba dalam hubungannya dengan penjualan, total aktiva maupun modal sendiri.

Profitabilitas dalam penelitian ini diproksikan dengan return on asset. Return on asset dapat dihitung dengan cara membagi earning after tax (laba setelah pajak) terhadap total aset. Rumus untuk menghitung return on asset adalah sebagai berikut (Hanafi dan Halim, 2012:81):

Return on Asset (ROA) $=\frac{\text { EAT }}{\text { Total Aset }}$ X 100\%

\section{Aktiva berwujud}

Tangibilitas aset diartikan sebagai ukuran untuk tingkat kredit yang dapat ditawarkan perusahaan kepada kreditornya. Rasio aktiva tetap terhadap total aset yang tinggi memberi kreditor tingkat keamanan yang tinggi karena mereka dapat melikuidasi aset jika terjadi kebangkrutan (Baker \& Martin, 2011).

Aktiva berwujud pada penelitian ini dihitung dengan cara membagi nilai aktiva tetap terhadap nilai total asset, rumusnya adalah sebagai berikut (Alipour et al, 2015):
Aktiva berwujud $=\frac{\text { Fixed Asset }}{\text { Total Asset }} \times 100 \%$

\section{Ukuran Perusahaan}

Menurut Hartono (2008:254) ukuran perusahaan (firm size) adalah besar kecilnya perusahaan dapat diukur dengan total aktiva/besar harta perusahaan dengan menggunakan perhitungan nilai logaritma total aktiva.

Mengacu penelitian yang dilakukan Kieschnick dan Moussawi (2018) ukuran perusahaan diproksikan dengan logaritma natural total aset perusahaan selama satu tahun tertentu. Size $=$ Ln $($ Total Aset). Data ukuran perusahaan perusahan biasanya dinyatakan dalam satuan mata uang, biasanya dalam rupiah atau dollar, perbedaan satuan biasanya menyebabkan adanya data outlier, sehingga perlu dilakukan transformasi ke dalam bentuk LN (logaritma natural) supaya satuannya menjadi setara.

\section{Pertumbuhan Perusahaan}

Menurut Kasmir (2012:107) Rasio pertumbuhan (Growth Ratio) merupakan rasio yang menggambarkan kemampuan perusahaan mempertahankan posisi ekonominya di tengah pertumbuhan perekonomian dan sektor usahanya.

Mengacu pada penelitian Saeed et al. (2014) pertumbuhan perusahaan diproksikan dengan pertumbuhan penjulan. Pertumbuhan penjualan dapat dihitung dengan rumus sebagai berikut:

Sales Growth $=\frac{\text { Penjualan }_{\mathrm{t}}-\text { Penjualan }_{\mathrm{t}-1}}{\text { Penjualan }_{\mathrm{t}-1}} \times 100 \%$

\section{Umur Perusahaan}

Umur perusahaan yaitu seberapa lama suatu perusahaan mampu untuk bertahan, bersaing, dan mengambil kesempatan bisnis yang ada dalam perekonomian (Syafi'i, 2013).

Beberapa studi memproksikan usia perusahaan dengan waktu antara pendirian perusahaan sampai sekarang perusahaan berdiri (dalam tahun). Studi lain mengukur usia perusahaan dengan waktu antara go public sampai sekarang (dalam tahun). Penelitian ini memilih untuk fokus pada ukuran kedua dimana usia perusahaan diproksikan sebagai waktu perusahaan mulai IPO sampai sekarang. 


\section{Hasil dan Pembahasan}

\section{Statistik Deskriptif}

Hasil statistik deskriptif disajikan pada tabel 3.

Tabel 3. Hasil Analisis Statistik Deskriptif

\begin{tabular}{lrrrr}
\hline \multicolumn{1}{c}{ Variabel } & \multicolumn{1}{c}{ Min } & Max & Mean & $\begin{array}{c}\text { Std. } \\
\text { Deviati } \\
\text { on }\end{array}$ \\
\hline Struktur Modal & 0.0357 & 1.5932 & 0.6671 & 0.3895 \\
Profitabilitas & -0.0493 & 0.3161 & 0.0542 & 0.0600 \\
Aktiva Berwujud & 0.0018 & 0.4013 & 0.0900 & 0.0882 \\
Ln Size & 12.8121 & 17.8546 & 15.6710 & 1.0589 \\
Pertumbuhan & -0.8712 & 2.9871 & 0.1420 & 0.4757 \\
perusahaan & 11.00 & 29.00 & 19.50 & 4.32 \\
\hline Umur perusahaan & & & & \\
\hline
\end{tabular}

Variabel pertama yaitu struktur modal. Struktur modal dalam penelitian ini merupakan variabel terikat, diukur dengan debt to equity ratio. Hasil analisis statistik deskriptif untuk variabel struktur modal diketahui nilai minimumnya adalah sebesar 0.0357 atau 3.57 persen.. Nilai maksimum variabel struktur modal yaitu sebesar 1.5932 atau 159.32 persen. Rata-rata nilai debt to equity ratio untuk perusahaan pada sektor properti dan real estate adalah sebesar 0.6671 atau 66.71 persen.

Variabel kedua yaitu profitabilitas. Profitabilitas dalam penelitian ini diukur dengan return on asset. Hasil analisis deskriptif menunjukkan nilai return on asset berkisar antara -0.0493 atau -4.93 persen sampai dengan 0.3161 atau 31.61 persen. Ratarata return on asset perusahaan pada sektor properti dan real estate yaitu sebesar 0.0542 atau 5.42 persen.

Variabel ketiga yaitu aktiva berwujud. Aktiva berwujud dalam penelitian ini diukur rasio aset tetap terhadap total aset. Hasil analisis deskriptif menunjukkan nilai aktiva berwujud berkisar antara 0.0018 atau 0.18 persen sampai dengan 0.4013 atau 40.13 persern. Rata-rata nilai aktiva berwujud perusahaan pada sektor properti dan real estate yaitu sebesar 0.0900. atau 9 persen.

Variabel keempat yaitu ukuran perusahaan. Ukuran perusahaan dalam penelitian ini diukur dengan $\mathrm{LN}$ total aset. Hasil analisis deskriptif menunjukkan nilai $\mathrm{LN}$ total aset berkisar antara 12.8121 sampai dengan 17.851. Rata-rata nilai LN total aset perusahaan pada sektor properti dan real estate yaitu sebesar 5.6710.

Variabel kelima yaitu pertumbuhan perusahaan. Pertumbuhan perusahaan dalam penelitian ini dihitung dengan cara membagi selisih penjualan tahun $\mathrm{t}$ dengan penjualan $\mathrm{t}-1$ terhadap penjualan $\mathrm{t}-1$. Hasil analisis deskriptif menunjukkan nilai pertumbuhan perusahaan berkisar antara -0.8712 atau -87.12 persen sampai dengan 2.9871 atau 298.71 persen. Rata-rata nilai pertumbuhan perusahaan pada sektor properti dan real estate yaitu sebesar 0.1420 . atau 14.20 persen.

Variabel keenam yaitu umur perusahaan. Umur perusahaan dalam penelitian ini dihitung sejak perusahaan melakukan IPO. Hasil analisis deskriptif menunjukkan nilai umur perusahaan berkisar antara 11 tahun sampai dengan 29 tahun. Rata-rata nilai umur perusahaan pada sektor properti dan real estate yaitu 19.50 tahun.

\section{Uji Asumsi Klasik}

Asumsi klasik yang dilakukan dalam penelitian ini terdiri dari 4 uji yaitu normalitas, multikolinearitas, heteroskedastisitas, dan autokorelasi. Hasil uji normalitas menggunakan metode Kolmogorov Smirnov membuktikan bahwa data memiliki distribusi normal ditunjukkan dengan nilai asymp sig. dari hasil normalitas sebesar 0.943 , nilai tersebut lebih besar dari alpha 0.05 .

Metode yang digunakan untuk mendeteksi ada atau tidaknya multikolinearitas dalam penelitian ini yaitu dengan cara melihat nilai Variance Inflation Factor (VIF). Berdasarkan hasil pengujian, diperoleh nilai VIF masing-masing variabel bebas kurang dari 10, dengan demikian dapat disimpulkan bahwa tidak terdapat gejala multikolinearitas dalam model penelitian ini, atau dengan kata lain variabel bebas bersifat independen.

Metode yang digunakan untuk mendeteksi ada tidaknya gejala heteroskedastisitas dalam penelitian ini menggunakan metode park, yaitu dengan cara meregresikan variabel bebas terhadap nilai logaritma natural residual kuadrat. Berdasarkan hasil analisis diperoleh nilai signifikansi untuk masing-masing variabel bebas adalah lebih besar dari alpha 0.05 sehingga dapat diambil kesimpulan bahwa model terbebas dari gejala heteroskedastisitas. 
Metode yang digunakan untuk mengetahui ada tidaknya gejala autokorelasi pada penelitian ini yaitu metode Durbin Watson. Berdasarkan hasil analisis diketahui nilai Durbin Watson (DW) sebesar 1.860. Nilai tersebut lebih besar dari nilai DU dan lebih kecil dari nilai 4-DU, dengan demikian dapat disimpulkan bahwa tidak terdapat autokorelasi dalam model penelitian.

\section{Analisis Regresi Linier Berganda}

Persamaan Regresi

Hasil analisis regresi berganda dapat dilihat pada tabel 4

Tabel 4.Hasil Analisis Regresi Berganda

\begin{tabular}{lc}
\hline \multicolumn{1}{c}{ Variabel } & Koefisien Regresi \\
\hline Konstanta & -2.560 \\
Profitabilitas & -1.109 \\
Aktiva Berwujud & 0.220 \\
Ln Size & 0.177 \\
Pertumbuhan & 0.120 \\
Umur perusahaan & 0.024 \\
\hline
\end{tabular}

Berdasarkan tabel 4 dapat dibuat persamaan regresi sebagai berikut:

Struktur modal $=-2.560-1.109$ Profitabilitas

$\begin{array}{lr}+\quad 0.220 & \text { Aktiva } \\ \text { Berwujud }+ & 0.177 \text { Ln } \\ \text { Size }+ & 0.120 \\ \text { Pertumbuhan } & + \\ \text { Umur + e } & \end{array}$

Berdasarkan hasil analisis diperoleh nilai R Square sebesar 0.398 , nilai tersebut dapat diartikan bahwa variabel profitabilitas, aktiva berwujud, ukuran perusahaan, pertumbuhan perusahaan, dan umur perusahaan mampu menjelaskan variabel struktur modal sebesar 39,8\% sedangkan $60,2 \%$ lainnya dipengaruhi oleh varibel lain yang tidak dimasukkan dalam model penelitian ini seperti variabel makro ekonomi seperti tingkat suku bunga, nilai tukar serta tingkat inflasi. Berdasarkan hasil analisis juga diperoleh nilai $\mathrm{F}$ sebesar 19.079 dengan nilai signifikansi sebesar 0.000 . Karena nilai signifikansi kurang dari alpha 0.05 maka dapat disimpulkan bahwa model atau variabel independen mampu memprediksi variabel dependennya atau model regresi sudah fit.

\section{Pengujian Hipotesis}

Uji t digunakan untuk mengetahui pengaruh dari variabel bebas terhadap variabel terikat secara individual. Kriteria statistik yang digunakan untuk melihat pengaruh variabel bebas terhadap variabel terikat yaitu dengan melihat nilai siginifikansi masing-masing variabel bebas. Jika nilai signifikansi $\leq 0.05$ maka hipotesis diterima, berarti variabel independen mempunyai pengaruh yang signifikan terhadap variabel dependen, sebaliknya jika nilai probabilitas $>0.05$ maka hipotesis di tolak karena variabel independen tidak mempunyai pengaruh yang signifikan terhadap variabel dependen. Nilai $t$ hitung dan nilai signifikansi masing-masing variabel independen dapat dilihat pada tabel berikut ini. Tabel 4.11. Nilai t hitung dan nilai signifikansi

\begin{tabular}{lrccc}
\hline \multicolumn{1}{c}{ Variabel } & Nilai t & $\begin{array}{c}\text { Signifi } \\
\text { kansi }\end{array}$ & Alpha & $\begin{array}{c}\text { Keputusa } \\
\mathrm{n} \\
\text { Hipotesis }\end{array}$ \\
\hline Profitabilitas & -2.456 & 0.015 & 0.05 & Terima \\
Aktiva berwujud & 0.746 & 0.457 & 0.05 & Tolak \\
Ukuran perusahaan & 6.821 & 0.000 & 0.05 & Terima \\
Pertumbuhan & 2.081 & 0.039 & 0.05 & Terima \\
perusahaan & 3.805 & 0.000 & 0.05 & Tolak \\
\hline Umur perusahaan & & & & \\
\hline
\end{tabular}

Pengujian Hipotesis Pertama

Pengujian hipotesis pertama bertujuan untuk menguji pengaruh profitabilitas yang diukur dengan return on asset terhadap struktur modal. Berdasarkan tabel 4.11 diketahui nilai $\mathrm{t}$ hitung variabel profitabilitas sebesar -2.456 dengan nilai signifikansi sebesar 0,015. Dengan menggunakan df (n-k$1=150-5-1=144)$ dan alpha 5\% diperoleh $\mathrm{t}$ tabel sebesar -1,655. Karena nilai $\mathrm{t}$ hitung bernilai negatif dan lebih kecil dari t tabel, didukung dengan nilai signifikansi yang lebih kecil dari 0,05 maka dapat disimpulkan bahwa secara parsial variabel profitabilitas berpengaruh negatif terhadap struktur modal, hal ini berarti bahwa semakin tinggi profitabilitas yang diperoleh perusahaan maka semakin rendah tingkat utang yang dimiliki perusahaan. Dengan demikian hipotesis pertama yang menyatakan "Profitabilitas berpengaruh negatif terhadap struktur modal." dapat diterima.

Pengujian Hipotesis Kedua

Pengujian hipotesis kedua bertujuan untuk menguji pengaruh aktiva berwujud terhadap struktur modal. Berdasarkan tabel 4.11 diketahui nilai $\mathrm{t}$ hitung variabel aktiva 
berwujud sebesar 0.746 dengan nilai probabilitas 0,457 . Dengan menggunakan $\mathrm{df}$ (n-k-1=150-5-1=144) dan alpha 5\% diperoleh $\mathrm{t}$ tabel sebesar 1,655. Karena nilai t lebih kecil dari t tabel, didukung dengan nilai signifikansi yang lebih besar dari 0,05 maka dapat disimpulkan bahwa secara parsial variabel aktiva berwujud tidak memberikan pengaruh signifikan terhadap struktur modal, hal ini berarti bahwa dalam konteks penelitian ini aktiva berwujud bukan merupakan variabel yang memberikan pengaruh signifikan terhadap struktur modal. Dengan demikian hipotesis kedua yang menyatakan "Aktiva berwujud berpengaruh positif terhadap struktur modal" ditolak.

\section{Pengujian Hipotesis Ketiga}

Pengujian hipotesis ketiga bertujuan untuk menguji pengaruh ukuran perusahaan terhadap struktur modal. Berdasarkan tabel 4.11 diketahui nilai t hitung variabel ukuran perusahaan sebesar 6.821 dengan nilai signifikansi sebesar 0.000 . Dengan menggunakan df $(\mathrm{n}-\mathrm{k}-1=150-5-1=144)$ dan alpha 5\% diperoleh $\mathrm{t}$ tabel sebesar 1,655. Karena nilai $t$ hitung bernilai positif dan lebih besar dari $\mathrm{t}$ tabel, didukung dengan nilai signifikansi yang lebih kecil dari 0,05 maka dapat disimpulkan bahwa secara parsial variabel ukuran perusahaan memberikan pengaruh positif terhadap struktur modal, hal ini berarti bahwa ukuran perusahaan yang semakin besar yang ditandai dengan meningkatnya total aktiva yang dimiliki akan berpengaruh terhadap meningkatnya tingkat utang perusahaan. Dengan demikian hipotesis ketiga yang menyatakan "Ukuran perusahaan berpengaruh positif terhadap struktur modal" dapat diterima.

\section{Pengujian Hipotesis Keempat}

Pengujian hipotesis keempat bertujuan untuk menguji pengaruh pertumbuhan perusahaan terhadap struktur modal. Berdasarkan tabel 4.11 diketahui nilai t hitung variabel pertumbuhan perusahaan sebesar 2.081 dengan nilai probabilitas 0,039 . Dengan menggunakan df $(n-k-1=150-5-1=144)$ dan alpha 5\% diperoleh $t$ tabel sebesar 1,655. Nilai signifikansi pertumbuhan perusahaan yang lebih kecil dari 0,05 dan nilai t hitung yang bernilai positif menunjukkan bahwa secara parsial variabel pertumbuhan perusahaan memberikan pengaruh positif terhadap struktur modal. Hal tersebut berarti perusahaan dengan pertumbuhan tinggi cenderung membutuhkan tingkat utang yang tinggi. Dengan demikian hipotesis keempat yang menyatakan "Pertumbuhan perusahaan berpengaruh positif terhadap struktur modal" dapat diterima.

Pengujian Hipotesis Kelima

Pengujian hipotesis keliama bertujuan untuk menguji pengaruh umur perusahaan terhadap struktur modal. Berdasarkan tabel 4.11 diketahui nilai $\mathrm{t}$ hitung variabel umur perusahaan sebesar 3.805 dengan nilai probabilitas 0,000 . Dengan menggunakan df (n-k-1=150-5-1=144) dan alpha 5\% diperoleh $\mathrm{t}$ tabel sebesar 1,655. Nilai signifikansi umur perusahaan yang lebih kecil dari 0,05 dan nilai $\mathrm{t}$ hitung yang bernilai positif menunjukkan bahwa secara parsial variabel umur perusahaan memberikan pengaruh positif terhadap struktur modal. Hal tersebut berarti perusahaan dengan umur yang lama cenderung membutuhkan tingkat utang yang tinggi. Hasil analisis tersebut tidak sesuai dengan pernyataan hipotesis yang telah dirumuskan. Hipotesis umur perusahaan dalam penelitian ini arahnya adalah negatif. Dengan demikian hipotesis kelima yang menyatakan "Umur perusahaan berpengaruh negatif terhadap struktur modal" ditolak.

\section{Pembahasan}

Pengaruh Profitabilitas terhadap Struktur Modal

Hasil analisis menunjukkan bahwa profitabilitas berpengaruh negatif terhadap struktur modal. Profitabilitas dalam penelitian ini diukur dengan return on asset. Return on asset menunjukkan persentase keuntungan yang diperoleh perusahaan dari hasil total aset yang dikelolanya. Hasil penelitian ini membuktikan bahwa perusahaan dengan keuntungan yang tinggi cenderung memiliki tingkat utang yang rendah. Hasil analisis deskriptif menunjukkan bahwa rata-rata profitabilitas pada sektor properti dan real estate selama periode 2013-2018 menunjukkan hasil yang positif dengan mencatatkan persentase keuntungan sebesar 5.42 persen. Sedangkan rata-rata debt to equity ratio nya sebesar 66.71 persen, hal tersebut menunjukkan bahwa rata-rata tingkat utang terhadap ekuitas perusahaan pada sektor properti dan real estate masih di bawah 100 
persen, artinya rata-rata utang nya masih belum melampau ekuitas nya.

Hasil penelitian ini mendukung penelitian sebelumnya yang dilakukan oleh Serghiescu and Vaidem (2014), Thippayana (2015), Mau et al (2015), Ariyani et al (2018), Acaravci (2015), Sakinah dan Anggono (2014), Alipour et al (2015) dan Noryati (2015) yang juga menyimpulkan bahwa profitabilitas memiliki kausalitas negatif terhadap struktur modal. Hasil penelitian ini menunjukkan bahwa sektor properti dan real estate di Indonesia cenderung lebih memprioritaskan dana internal sebagai sumber utama pendanaannya. Sedangkan sumber eksternal berupa utang merupakan sumber pendanaan alternatif.

Pengaruh Aktiva Berwujud terhadap Struktur Modal

Hasil analisis menunjukkan bahwa aktiva berwujud tidak memberikan pengaruh signifikan terhadap struktur modal. Hal ini berarti dalam konteks penelitian ini aktiva berwujud tidak memberikan bukti empiris sebagai prediktor struktur modal. Hasil analisis statistik deskriptif menunjukkan bahwa ratarata aktiva berwujud perusahaan pada sektor properti dan real estate adalah sebesar 9 persen. Nilai aktiva berwujud ini diduga terhitung rendah sehingga belum mampu memberikan pengaruh yang signifikan terhadap peningkatan atau penurunan debt to equity perusahaan. Seperti telah diketahui sebelumnya bahwa rata-rata nilai debt to equity ratio pada sektor properti dan real estate juga terhitung rendah, sehingga tidak menjadikan utang sebagai prioritas utama pendanaan perusahaan. Karena perusahaan cenderung memiliki lebih banyak ekuitas sehingga tidak memerlukan aset tetap dalam jumlah besar yang biasanya sangat umum dijadikan sebagai jaminan kepada bank untuk mempermudah memperoleh pinjaman dana.

Hasil penelitian ini berbeda dengan penelitian sebelumnya yang dilakukan oleh Murhadi (2011), Chandra (2017), Thippayana (2015), Noryati (2015) yang menyimpulkan aktiva berwujud berpengaruh positif terhadap struktur modal. Namun hasil penelitian ini konsisten dengan temuan pada hasil riset yang dilakukan oleh Sakinah dan Anggodo (2014) yang juga mendapati bahwa tidak adanya pengaruh signifikan dari aktiva berwujud terhadap struktur modal.

Pengaruh Ukuran perusahaan terhadap Struktur Modal

Berdasarkan hasil analisis ukuran perusahaan memberikan pengaruh signifikan terhadap struktur modal dengan arah positif. Artinya pada sektor properti dan real estate perusahaan dengan kepemilikan aset yang besar cenderung memiliki tingkat utang yang besar juga. Ukuran perusahaan dalam penelitian ini diukur dengna total aset yang dimiliki perusahaan. Perusahaan dengan kepemilikan aset yang besar tentu memiliki skala produksi yang besar. Skala produksi yang besar berkaitan dengan pembiayaan yang besar juga. Meskipun pada sektor properti dan real estate perusahaan cenderung menggunakan ekuitas sebagai opsi utama untuk mendanai operasional, tetapi tetap membutuhkan proporsi utang dalam jumlah persentase yang wajar. Penggunaan utang juga bisa memberikan manfaat bagi perusahaan yaitu berupa pengurangan pajak.

Hasil penelitian ini mendukung penelitian yang dilakukan oleh Noryati (2015), Ariyani et al (2018), Mau et al (2015), Wahome et al (2015) yang dalam hasil penelitiannya mendapati bahwa ukuran perusahaan berpengaruh positif terhadap struktur modal.

Pengaruh Pertumbuhan Perusahaan terhadap Struktur Modal

Hasil analisis menunjukkan bahwa pertumbuhan perusahaan memberikan pengaruh positif terhadap terhadap struktur modal, hal tersebut menunjukkan bahwa perusahaan dengan pertumbuhan tinggi cenderung membutuhkan tingkat utang yang tinggi. Penelitian ini mengukur pertumbuhan perusahaan dengan melihat penjualan perusahaan. Pertumbuhan penjualan berkaitan dengan peningkatan jumlah produksi dalam skala besar secara signifikan, untuk membiayai jumlah produksi yang besar tersebut perusahaan tentu saja membutuhkan dana yang cukup besar untuk memenuhi kekurangan dari dana internal yang dimiliki. Salah satu alternatif untuk memenuhi kebutuhan dana tersebut adalah melalui pendanaan eksternal berupa utang. Hasil statistik deskriptif menunjukkan bahwa rata-rata pertumbuhan 
perusahaan pada sektor properti dan real estate adalah positif dengan mencatat pertumbuhan sebesar 14.20 persen.

Hasil penelitian ini sejalan dengan penelitian sebelumnya yang dilakukan oleh Tronyeva (2013) serta Noryati (2015) yang menyimpulkan bahwa kausalitas antara pertumbuhan perusahaan dengan struktur modal adalah positif atau perusahaan dengan aset yang tinggi cenderung memiliki tingkat utang yang tinggi. Pengaruh Umur Perusahaan terhadap Struktur Modal

Hasil analisis menunjukkan bahwa umur perusahaan memberikan pengaruh positif terhadap struktur modal. Hasil tersebut dapat diinterpretasikan bahwa perusahaan dengan umur yang lama cenderung memiliki tingkat utang yang tinggi. Meskipun hasil analisis menunjukkan pengaruh signifikan umur perusahaan terhadap perusahaan namun hasil analisis ini tidak sesuai dengan hipotesis yang dirumuskan. Umur perusahaan berkaitan dengan pengalaman perusahaan dalam mengelola perusahaanya sehingga sudah dianggap mumpuni dalam mengelola risiko yang bakal dihadapi oleh perusahaan termasuk untuk urusan utang. Perusahaan dianggap sudah stabil dalam menjalankan operasionalnya. Meskipun perusahaan mempunyai rasio utang yang cukup tinggi karena sudah memiliki pengalaman sehingga memiliki keyakinan dan kepercayaan diri bahwa utang yang digunakan bisa memberikan nilai tambah bagi perusahaan dan perusahaan yakin bisa melunasi utangnya.

Hasil penelitian tersebut berbeda dengan penelitian sebelumnya yang dilakukan oleh Noryati (2015) serta Hall et al. (2004) yang menyimpulkan bahwa umur perusahaan memiliki kausalitas negatif terhadap struktur modal. Namun hasil penelitian ini mendukung penelitian sebelumnya yang dilakukan oleh Dhodary (2019) yang memberikan penegasan untuk hasil penelitian ini yaitu bahwa kausalitas antara umur perusahaan dengan struktur modal adalah positif, yang artinya perusahaan dengan usia yang semakin lama justru cenderung memiliki utang yang tinggi.

\section{Kesimpulan}

Berdasarkan hasil analisis yang telah dilakukan, maka dapat disusun kesimpulan sebagai berikut: (1) Profitabilitas berpengaruh positif terhadap struktur modal, sehingga hipotesis pertama diterima (2) Aktiva berwujud tidak memberikan pengaruh signifikan terhadap struktur modal, sehingga hipotesis kedua ditolak (3) Ukuran perusahaan berpengaruh positif terhadap struktur modal, sehingga hipotesis ketiga diterima (4) Pertumbuhan perusahaan berpengaruh positif terhadap struktur modal, sehingga hipotesis keempat diterimA (5) Umur perusahaan berpengaruh positif terhadap struktur modal, tetapi tidak sesuai dengan rumusan hipotesis, shingga hipotesis kelima ditolak.

\section{Implikasi}

Berdasarkan hasil analisis dari 5 variabel prediktor yang diteliti dalam penelitian ini hanya aktiva berwujud yang secara statistik tidak memberikan pengaruh signifikan terhadap struktur modal. Empat variabel lainnya yaitu profitabilitas, ukuran perusahaan, pertumbuhan perusahaan dan umur perusahaan memberikan pengaruh signifikan terhadap struktur modal. Bagi perusahaan di Bursa Efek Indonesia dan investor, temuan penelitian ini diharapkan dapat menjadi input yang berguna dalam pengambilan keputusan atau kebijakan pembiayaan suatu perusahaan. Beberapa rekomendasi terkait hasil penelitian ini yaitu sebagai berikut: (1) Bagi perusahaan dengan perolehan keuntungan yang besar bisa mengalokasikan sebagian keuntungannya untuk mendanai operasional perusahaan, dan bisa meminimalisir tingkat utang sehingga tidak terbebani dengan bunga utang (2) Pertumbuhan perusahaan dapat menjadi acuan dalam menentukan mekanisme pendanaan, apakah akan menggunakan dana internal atau dana eksternal. Perusahaan dapat menggunakan dana internal terlebih dahulu sebelum dana eksternal, karena dana internal bebas biaya bunga (3) Meningkatkan kegiatan pemanfaatan aset untuk memungkinkan perusahaan menjadi lebih efektif dan efisien dalam operasinya, sehingga mengurangi penggunaan hutang berbunga, dan menghasilkan peningkatan kinerja keuangan serta nilai perusahaan (4) Bagi perusahaan yang sudah memiliki umur yang cukup lama bisa lebih memanfaatkan pengalamannya untuk terus eksis dan sustainable dalam mengelola aktiva serta risiko supaya perusahaan bisa terus membukukan kinerja keuangan yang bagus. 


\section{Keterbatasan Penelitian dan Agenda Penelitian Mendatang}

Beberapa keterbatasan dalam penelitian ini adalah nilai $\mathrm{R}$ Square sebesar 0.398 nilai ini masih bisa ditingkatkan dengan mencari prediktor lain yang bisa berpengaruh terhadap struktur modal seperti variabel makro ekonomi seperti tingkat suku bunga, nilai tukar serta tingkat inflasi. Penelitian mendatang bisa melakukan penyempurnaan pada penelitian ini dengan menambahkan variabel tersebut serta menguji coba pada sektor yang berbeda dengan sampel yang lebih besar dan periode waktu penelitian yang lebih panjang, diharapkan memberikan hasil penelitian dan kesimpulan yang lebih komprehensip tentang determinan struktur modal serta bisa memberikan dasar generalisasi yang lebih kuat dalam pengambilan kesimpulan hasil penelitian.

\section{Daftar Pustaka}

Acaravci, Songul Kakilli. 2015. The Determinants of Capital Structure: Evidence from the Turkish Manufacturing Sector. International Journal of Economics and Financial Issues Vol. 5, No. 1, 2015, pp.158-171

Alipour, Mohammad., Mir Farhad Seddigh Mohammadi., and Hojjatollah Derakhsahan. 2015. Determinants of CapitalStructure: An Empirical StudyOf Frms In Iran. International Journal of Law and Management, Vol. 57 Iss 1 pp. $53-83$

Ariyani, Hilma Faza., Irene Rini Demi Pangestuti., dan Susilo Toto Raharjo. 2018. The Effect Of Asset Structure, Profitability, Company Size, And Company Growth On Capital Structure (The Study of Manufacturing Companies Listed on the IDX for the Period 2013 - 2017). Jurnal Bisnis Strategi, Vol. 27 No. 2, hal 123-136.

Baker, Malcolm., and Jeffrey Wurgler. 2002. Market Timing and Capital Structure. The Journal Of Finance, Vol. Lvii, No. 1, Feb. 2002
Baker, H. Kent and Gerald S Martin. 2011. Capital Structure and Corporate Financing Decision: Theory, Evidence and Practice.USA: John Wiley \& Sons Ltd.

Bernstein, L., dan J.J. Wild. 1998. Financial Statement Analysis: Theory, Applications, and Intreperation, 6th ed. New York: Irwin McGraw-Hill.

Brealey, R. A. \& Myers, S. C. 1991. Principles of Corporate Finance, 4th edition. McGraw Hill Inc.

Brigham, Eugene F. dan Houston, Joel F. 2011. Dasar-dasar Manajemen Keuangan Terjemahan. Edisi 10. Jakarta: Salemba Empat.

Caglayan, Ebru and Nazan Sak. 2010. The determinant of Capital Structure: Evidence from the Turkish Banks. Journal of Money, Investment, and Banking, ISSN 1450-288X Issue 15, pp. $57-65$

Chandra, Ambrosius Fabian. 2017. Company Size, Profitability, Tangibilitas, Free Cash Flow, And Growth Opportunity That Affect The Capital Structure In Manufacturing Company. Jurnal Manajemen Bisnis Dan Kewirausahaan, Volume 02/No.2/November-2017 : 17-26

Data, Ari., Taher Alhabsji, Sri Mangesti Rahayu, Siti Ragil Handayani. 2017. Effect of Growth, Liquidity, Business Risk and Asset Usage Activity, Toward Capital Structure, Financial Performance and Corporate Value (Study at Manufacturing Companies Listed in Indonesia Stock Exchange in 2010-2015). European Journal of Business and Management, Vol.9, No.24 available on www.iiste.org

Deitiana, Tita., dan Robin. 2016. The Effect Of Firm Size, Profitability, Tangibility, Non-Debt Tax Shield And Growth To Capital Structure On Banking Firms Listed In IndonesiaStock Exchange 
From 2007-2012. South East Asia Journal of Contemporary Business, Economics and Law, Vol. 10, Issue 1 (Aug.) Issn 2289-1560.

Deloof, M. and Overfelt, W.V. 2008. Were Modern Capital Structure Theories Valid In Belgium Before World War I?"Journal of Business Finance \& Accounting, Vol. 35 Nos 3/4,pp. 491515.

Dhodary, Shanker. 2019. Determinants of Capital Structure on Trading and Manufacturing Enterprises: A Case of Nepal. NCC Journal, Vol. 4, No.1.

Djakman, Chaerul., dan Gina Halomoan. 2001. Pengujian Pecking Order Hypothesis pada Emiten di Bursa Efek Jakarta 1994 dan 1995. The Indonesian Journal of Accounting Research, Vol 4, No 3.

Ezeoha, A., and F. Botha. 2012. Firm age, Collateral Value and Access to Debt Financing in an Emerging Economy: Evidence from South Africa.

Ferdinand, Augusty. 2014. Metode Penelitian Manajemen. BP Universitas Diponegoro. Semarang.

Filatotchev, I., Toms, S., and Wrigth, M. 2006. The Firm's Strategic Dynamic and Corporate Governance Life Cycle. International Journal Management Finance, 2, 256-279.

Gill, Amarjit, Nabu Biger, Chenping Pai, and Smita Bhutani.2009. The Determinant Of Capital Structure In The ServiceIndustry: Evidence from United States. The open Business Journal, No.2, pp.48-53

Gitman, Lawrence. J and Chad J. Zutter. 2012. Principles of Managerial Finance. 13th edition. England: Pearson Education Limited

Ghozali, Imam. 2006. Aplikasi Analisis Multivariate dengan Program SPSS
(Edisi Ke 4). Semarang: Badan Penerbit Universitas Diponegoro.

Gujarati, Damodar N. 2006. Ekonometrika Dasar. Jakarta : Penerbit Erlangga

Hall, G., Hutchinson, J., Michaelas, N., 2004. Determinants of The Capital Structure ofEuropean SMEs. Journal of Business \& Accounting. 31, 711-728.

Hanafi, Mahduh dan Abdul Halim. 2012. Analisis Laporan Keuangan. Yogyakarta: (UPP) STIM YKPN.

Hartono, Jogiyanto. 2008. Teori Portofolio dan Analisis Investasi. Edisi Kelima. Yogyakarta: BPFE.

Hidayat Muchtar. 2011. Manajemen Aset (Privat dan Publik). Yogyakarta: LaksBang

Husnan, Suad. 2002. Manajemen Keuangan Teori Dan Praktek. Yayasan Badan Penerbit Gajah Mada. Yogyakarta.

Irawati, Susan. 2006. Manajemen Keuangan. Pustaka: Bandung.

Jensen dan Meckling. 1976. The Theory of The Firm: Manajerial Behavior, Agency Cost, and Ownership Structure. Journal of Financial and Economics, 3:305-360.

Johnson, W., Karpoff, J., Yi, S., 2016. The Lifecycle of Firm Takeover Defenses. University of Washington Foster School of Business. Working Paper.

Joni dan Lina. 2010. Faktor-Faktor Yang Mempengaruhi Struktur Modal. Jurnal Bisnis dan Akuntansi, Vol.12, No. 2, Hlm. 81 - 96.

Kasmir. 2012. Analisis Laporan Keuangan. Jakarta: PT. Raja Grafindo Persada.

Kieschnick, Robert., and Rabih Moussawi. 2018. Firm Age, Corporage Governance, and Capital Structure Choice. Journal of Corporate Finance 48 (2018) 597-614 
Lemmon, M.L. and Zender, J.F. 2010. Debt Capacity And Tests Of Capital Structure Theories. Journal of Financial and Quantitative Analysis, Vol. 45 No. 5, pp. 1161-1187.

Liu, Yuanxin and Jing Ren. 2009. An Empirical Analysis on the Capital Structure of Chinese listed IT Companies. International Journal of Business and Management, Vol.4, no.8, pp.46-51

Machfoedz, M., 1994. Financial Ratio Analysis and The Prediction of Earnings Changes In Indonesia. Kelola Gadjah Mada University Business Review 7: pp. 114-134.

Mau, Jefrianus., Indri Prasasyaningsih., dan Putriana Kristanti. 2015. Pengaruh Profitabilitas, Umur, Dan Ukuran Perusahaan Terhadap Struktur Modal. JRAK, Volume 11, No 2 Agustus 2015

Mishkin, Frederic S and Stanley G. Eakins. 2006. Financial Market and Institutions Fifth Edition. USA: Pearson-Addison Wesley.

Murhadi, W.R. 2011. Determinan Struktur Modal: Studi di Asia Tenggara. Jurnal Manajemen dan Kewirausahaan, Vol 13: $91-98$

Moradi, Amir., and, Elisabeth Paulet. 2019. The Firm-Specific Determinants Of Capital Structure - An Empirical Analysis Of Firms Before And During The Euro Crisis. Research in International Business and FinanceVolume 47, Pages 150-161

Nasruddin, M. M. 2004. Faktor-Faktor yang Menentukan Keputusan Struktur Modal: Studi Empirik pada Perusahaan Industri Farmasi di Bursa Efek Jakarta. Jurnal Akuntansi \& Investasi, Vol. 5, No. 1 Januari: 47-61.

Noryati, Ahmad. 2015. Does Age of Firm Determine Capital Structure Decision? Evidence from Malaysian Trading and
Service Sector. International Business Management, 9 (3): 200-207, 2015.

Peterson, M. A. \& Rajan, R. G.. 1994. The Benefits Of Lending Relationships; Evidence FromSmall Business Data'. Journal of Finance, 49: 3-38.

Rajan, Raghuram G., dan Luigi Zingales. 1995. What Do We Know about Capital Structure? Some Evidence from International Data. The Journal of Finance, Vol L, No 5.

Ross, S.A., R.W. Westerfield., and B.D. Jordan. 2008. Fundamentals of Corporate Finance, $10^{\text {th }}$ Edition. McGraw-Hill.

Saeed, Rashid. Munir, Hafiza Mubeen. Lodhi, Rab Nawaz., Riaz, Ayesha. Iqbal, Amber. 2014. Capital Structure And Its Determinants: Empirical Evidence From Pakistan's Pharmaceutical Firms. Journal Basic Applied Science, 4 (2):115-125.

Saidi. 2004. Faktor-Faktor yang Mempengaruhi Struktur Modal pada Perusahaan Manufaktur Go Publik di BEJ tahun 1997-2002. Jurnal Bisnis dan Ekonomi. Vol.11,No.1.

Sakinah, Alida Nur., dan Achmad Herlanto Anggono. 2014. Analysis Of Determinants Of Capital Structure Of Plantation Companies In Indonesia (Case Study Public Listed Plantation Companies 2006- 2012). Journal of Business And Management, Vol. 3, No.1, 2014: 21-32

Sartono, Agus., dan Sriharto Ragil. 2010. Manajemen Keuangan Teori dan Aplikasi. Edisi Keempat. Yogyakarta: BPFE.

Serghiescu Laura., and Viorela Ligia Văidean . 2014. Determinant Factors of the Capital Structure of a Firm-an Empirical Analysis. Procedia Economics and FinanceVolume 15, 2014, Pages 1447-1457 
Setyawan, S. H., dan H. Laksito. 2008. Pengujian Pecking Order Theory pada Emiten Syariah di Bursa Efek Jakarta. Jurnal Keuangan dan Perbankan, Vol. 12, No.1 Januari: 22-28.

Sheikh, N.A. and Wang, Z. 2011. Determinants of Capital Structure An Empirical Study Of Frms In Manufacturing Industry of Pakistan. Managerial Finance, Vol. 37 No. 2, pp. 117-133.

Sudarno. 2005. Analisis Faktor-Faktor Yang Mempengaruhi Struktur Modal Perusahaan Sektor Infrastruktur, Utilitas dan Transportasi Pada BEJ. Tesis. Universitas Riau. Riau.

Sugiarto. 2009. Struktur Modal, Struktur Kepemilikan Perusahaan, Permasalahan Keagenan \& Informasi Asimetri. Yogyakarta: Graha Ilmu.

Sugiyono. 2009. Metode Penelitian Kuantitatif, Kualitatif dan $R \& D$. Bandung: Alfabeta

Suharli, Michell. 2006. Akuntansi untuk Bisnis Jasa dan Dagang, Edisi Pertama Graha Ilmu: Yogyakarta.

Suliyanto. 2011. Ekonometrika Terapan: Teori Dan Aplikasi Dengan SPSS. Yogyakarta: Penerbit ANDI

Syafi'i, Imam. 2013. Karakteristik Perusahaan Dan Struktur Modal Pada Perusahaan Sektor Makanan-Minuman. Media Mahardika, 11(3), h:1-30

Thippayan, Pornpen. 2014. Determinants of Capital Structure in Thailand. Procedia - Social and Behavioral SciencesVolume 143, Pages 10741077

Titman, S. dan Wessels, R. 1988. The Determinants of Capital Structure Choice. The Journal of Finance, 43 (1) March, 1-19.
Ulum, Ihyaul. 2009. Intellectual Capital:Konsep dan Kajian Empiris. Yogyakarta: Graha Ilmu.

Wahome, Michael Njogu., F. Memba., and Willy Muturi. 2015. The Effects Of Firm Size And Risk on Capital Structure Decisions of Insurance Industry in Kenya. International Journal of Scientific and Research Publications, Volume 5, Issue 8, August 2015.

Wijaya, Sienly Veronica., dan Bram Hadianto. 2008. Pengaruh Struktur Aktiva, Ukuran, Likuiditas, dan profitabilitas terhadap Struktur Modal Emiten Sektor Ritel di BEI: Sebuah Pengujian Hipotesis Pecking Order. Jurnal Ilmiah Akuntansi, 7 (1): 71-82.

Zélia Serrasqueiro and Ana Caetano. 2015. Trade-Off Theory Versus Pecking Order Theory: Capital Structure Decisions In A Peripheral Region Of Portugal. Journal of Business Economics and Management, Volume 16: 445-466. 